DEPARTMEINT OF COMIMERCE AND LABOR BUREAU OF FISHERIES GEORGE M, BOWERS, Commlntoner

EFFECTS OF EXPLOSIVE SOUNDS, SUCH AS THOSE PRODUCED BY MOTOR BOATS

\title{
AND GUNS, UPON FISHES
}

Bureau of Fisheries Document No, 752

WASHINGTON

GOVERNIMENT PRINTING OFFICE I911 


DEPARTMENT OF COMMERCE AND LABOR BUREAU OF FISHERIES

GEORGE M. BOWERS, Commissioner

\section{EFFECTS OF EXPLOSIVE SOUNDS, SUCH AS THOSE PRODUCED BY MHOTOR BOATS AND GUNS, UPON FISHES}

Bureas of Fisheries Document No. 752

WASHINGTON

GOVERNMENT PRINTING OFFICE 1911 
an ats 
EFFECTS OF EXPLOSIVE SOUNDS, SUCH AS THOSE PRODUCED BY MOTOR BOATS AND GUNS, UPON FISHES

\author{
By G. H. Parker, S. D. \\ Professor of Zoology, Hariard Universily
}

Bureau of Fisheries Document No. 752 



\title{
EFFECTS OF EXPLOSIVE SOUNDS, SUCH AS THOSE PRODUCED BY MOTOR BOATS AND GUNS, UPON FISHES.
}

\author{
By G. H. Parker, S. D., \\ Professor of Zoology, Harvard University.
}

\section{SENSE OF HEARING IN FISHES.}

That sounds affect many fishes has long been recognized by fishermen and naturalists. No less an authority than Izaak Walton declared that it should be a rule with him to make as little noise as possible when he was fishing, lest he be heard and catch no fish. Nevertheless it has been only within the last few years that the sense organs concerned with the reception of sound in fishes have been definitely identified.

Using the term sound to include any vibrations of the water, from such slight movements as result from waves and currents to the vibrations that emanate from the impact of solid bodies under water or from the more violent discharge of explosives, it may be said that sounds affect fishes through three sets of sense organs-the skin, the lateral-line organs, and the ears. Within recent years it has been demonstrated that a fish ean feel sounds through its skin in much the same way that a human being can feel the vibrations of a musical instrument when his hand is in contact with it. It has also been demonstrated that certain fishes sense relatively low vibrations, such as trembling movements of the water, by means of the lateral-line organs. And furthermore, though this point has been disputed, it seems clear to the writer through work carried out under the auspices of the Bureau of Fisheries that the internal ears of fishes are not only organs for the adjustment of bodily motions and equilibrium, but also organs of hearing.

\section{THE QUESTION OF MOTOR-BOAT NOISES.}

If, then, fishes are sensitive through so many channels to sounds, the question naturally arises as to the effect of the introduction of motor boats and other sound-producing mechanisms on the fishes of 
our shores. Are such devices favorable, inert, or prejudicial to our fisheries, and, if prejudicial, in what ways can they be modified to make them least harmful?

Motor boats driven by exploding gasoline are equipped, as a rule, with an escape pipe which is situated close to the level of the water and through which the exploded gas is discharged in violent jets. This pipe is sometimes so arranged that its end may be dropped below the water level or kept in the air. When the gas is delivered into the air each discharge is usually accompanied by a familiar explosive noise of much penetration. When the delivery is into the water the sound is greatly muffled and freed for the most part from its objectionable penetrating charicter. This method of reducing the noise is so easily applied that in certain communities efforts have been made to require all motor boats to be thus muffled, at least between certain hours. The objection from the standpoint of the motor boats to this form of muffling comes from the fact that when the escape pipe is under water the obstruction to the free outward passage of the gases is so much increased that the efficiency of the motor is considerably reduced, and hence the running of the boat is impaired.

To the human ear under ordinary circumstances most motor boats either with or without mufflers are noisy appliances, generating sounds that are carried a long distance through the air. But in the water these sounds are very much less penetrating. To test this, a 7 -horsepower motor boat with an exceptionally loud sound was run in open water and an observer plunged under the surface as the boat passed. When within 10 or 12 feet of the boat, whose escape pipe was in the air, the explosions of the gas could be faintly heard, though they were disagreeably loud to the observer when in the air. With the escape pipe under water and at the same distance as before the noise of the explosions could scarcely be detected at all under water. Thus both methods of running the boat delivered into the water surprisingly little sound as compared with what escaped into the air, and of the two conditions the muffled boat yielded to the water much less sound than the unmuffled boat.

In testing the effect of the motor-boat noises on fishes, a number of kinds of fish known to be sensitive to sounds, such as killifish (Fundulus heteroclitus), young scup (Stenotomus chrysops), and young lingfish (Menticirrhus saxatitis) were placed in a large wooden cage, 4 feet square by about 2 feet deep, whose walls were of strong netting. This cage was fastened in quiet water at the end of a float and a motor boat of $3 \frac{1}{2}$ horsepower and with a penetrating noise was started at a distance of some 400 feet from the cage and run at full speed past it. 
An observer was stationed on the float to note any response marte by the fish. 'Tests rere made with the escape pipe out of water and with it under water, but in neither instance was there any alpparent effect upon the fishes. Most of these fishes, and especially the killifish, go down into deeper water when only shightly disturbed, but in these trials they remained playing about on the smface of the water while the boat passed and were in no observale may disturbed until the swash from the boat struck the cage, whereupon they generally dove to the deeper part of the receptacle.

Another test of a like kind was carried ont on mackerel (wrember scombrus). Nbout 30 of these fish that had heen for one or two days in a large pocket at the end of a pound net alont a quartel of a mile from shore were gathered together by having the pocket pursed up into a space about 2.5 foet square and 10 feet deepr. In this space they swam slowly about in a circle near the top of the water.

When an observer stationed in a boat at the edge of the pocket rose in the boat the fish rery usually went to the bottom of their inclosure, to return to the surface after the observer had taken his seat again. While the observer Was sitting and watching the fish a second person ran a motor boat over a circular course alout half a mile in circumference, the course passing close to the pocket at one point. Is the motor boat passed the pocket the fish were closely scrutinized by the observer. In no instance, either with the escape pipe of the motor boat above water or under water, dir the mackerel sink into the deeper part of the pocket nor did they show in any other observable way that they were clisturbed by the noise from the boat. Seven of them were then isolated in the cage previously mentioned and tested under close inspeetion by rumming the motor boat past the eage, but again the mackerel gave no evidence of being disturbed by the noise.

Athough these tests seem to be quite conclusive in showing that the faint noises produced in the water hy a motor boat have no marked effect on the ordinary activities of certain fishes, it is not impossible that the same noises may interfere with other activities of these fishes, such as feeding. pairing. egg laying, etc. The only tests in this direction that were carried out had to do with feeding. IIungry killifish, seup, and kingfish were placed in the cage previously used and the cage was fastened to a float so that a motor boat could pass close to it. When the fish were feeding vigorously the motor boat was run by the cage several times, hut in no case dicl the fish give up feeding in consequence of the noise.

Another test was made with baited lines. 'Two baited fish lines were lowered from the edge of a wharf until the bait was about fi feet under water. In a short time the two baits were surrounded by 
cunners (Tautogolabrus adspersus), which began to nibble actively. A motor boat was now backed up under its omn power from a distance of about 50 feet till its stern was directly over the baited lines. During the approach of the motor boat the fishes continued to nibble, notwithstanding the increasing noise, till the boat was within 6 feet of the lines, whereupon the fishes ceased nibbling. On running the motor boat a rray for a short distance, 6 to 8 feet, vigorous nibbling recommenced. It is difficult to say whether the cessation of nibbling, which regularly occurred when the stern of the boat was brought close to the lines. was due to the noise that reached the fishes or to the churning of the water in their neighborhood by the propeller of the hoat. Howerer this may be, it is certain that cunners can be driven from bait by a motor boat only when it is rery close to them and that they are apparently uninfluenced by the same boat at a distance of 10 feet or so.

If a cunner can be driven from bait by the disturbance from a motor boat close at hand, other fish may be affected in a like manner, and shonld these be more sensitive to noises than the cunners, it is possible that they may be influenced when boats are at greater disiances than 6 to $s$ feet. There is, however, very little conclusive cridence on this point. In August, about the dock at Woods Hole, roung bluefish (Pomatomus saltatrix) are not uncommon. They are often angled for with rod and line and afford much sport for the local fishermen. They bite well, even with motor boats making much noise in the harhor and passing the dock at a distance of about a hundred feet. If. however, a motor boat comes close to the dock. they are almost certain to cease biting for a quarter of an hour or so. Observations of this kind are by no means conchusive, but they favor the opinion that some fishes are disturbed by the noises from motor boats, though these risturbances are always very temporary and local.

The noises produced by motor boats have only a slight and, local influence on fishes, not only because the noises that really get into. the water are very faint, but probably because they reach the fish in the most farorable way for nonstimulation. Most persons who have experimented with the effects of sound on fishes have been struck with the fact that after a fish has responded once or twice to a given sound, it often ceases to respond to further stimulation for some considerable time, and in experiments of this kind it is usual to allow relatively long intervals of time to elapse betreen tests in order that the fishes may return to a receptive state. In the approach of a motor boat the sound that first reaches the fish must be far too faint to call forth any response, and this sound grows so gradunlly in intensity and with such rapid reiteration that the fish probably acquires the state of nonreaction to sound by the time the stimulus 
has grown to such an intensity as would have been effective had a single shock been delivered at once to the fish. 'The gradual anpproach of the boat, then, does away with the element of contrast between silence and loud noise, and the result is just the reverse of that of summation, so often seen in the application of minimal stimuli to sense organs; the fish fails to respond.

\section{RESPONSE TO THE SOUND OF GUNSHOTS.}

If this explanation of the general ineflectivenens of motor boats in disturbing fishes is correct, then these animals ought to be responsive at least to single, loud noises generated "lose to the water. As long ago as 1782 Ilunter demonstrated that fishes were responsive to the discharge of a fowling piece. In his account of the internal ears of fishes he states that-

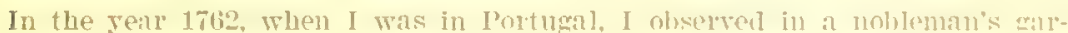
den near Lisbon a small tishpond, full of different kinds of fish. Its bottom was level with the ground and wats made by forming a hank all round. 'ligere was a shrubbery close to it. Whilst I was lying on the lank, observing the fisle swim ahout, I desired a crentleman who was with me to take a lomberl sun aud go behind the shrubs and fire it. The reasm for soing behind the shembs was that there might not he the least peflection of lisht. The instant the report was malde the tisly appeitren to be all of one mind, for they ranisherb

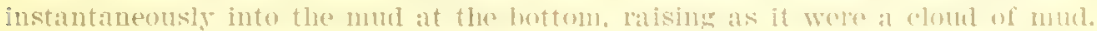

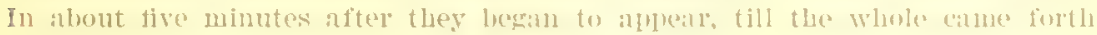
again.

It is quite evident from this ob-eration by IInnter that timbs can be disturbed by the discharge of a gun in the air. eren when it is some distance from them.

'lo test the eflect of single, loud noines on fishes seremal Fumblus mere liberated in a cage, and after they hat become quieterl a fow ing piece was discharerel a fer feet from them. lut in such a position that they could not see it. It the report of the amm most on the fishes gare a single leap forwald and to one sille. This was several times repeated at considerable intervals and invariably with the same results. Bait was then thoown into the carere and while the Fundulus were busy tuskling with this food the grun was anilin discharged. They inmediately forsook the hait, but in half a minute they had returned to it with full vigor. From theme tests it is evident that Fundulus is easily disturbed by such at moine in the ar as the clischarge of a gun, but it is also evident that this disturbance is of a very temporary kind.

To ascertain something of the strength of the somet stimulus that caused the Fundulus to react an observer dove under the water, and while he was there the rum was discharead in mun the same relat tion to him as it had heen to the fishes. Althomerh the report of the gum in the air was almost deafening. when it was heard moler 
a foot or so of water it resenbled the pop of a soda-water bottle both in quality and in intensity. This great reduction in intensity of the sound, as in the case of the motor-boat sounds, results from the reflection of most of the sound from the surface of the water, and hence its failure to enter the water. Iet the little that clid enter the water sufliced to stimulate the fishes.

Fundulus is linomu to be quite sensitive to sound, but the fact that it lives under water renders it relatively inacessible to sounds, since most sounds originate in the air. This explains why Fundulus and most other fishes fail to respond to the human voice. It is not that the human voice in itself is not strong enough to stimulate a fish. but rather that so little sound from it enters the water that stimulation is impossible. The surface between water and air is for fishes an eflective screen through which very little sound can pass.

With the view of ascertaining something of the etfectiveness of a gun report as a stimulus for Fundulus, trials were made by firing the gun at various distances from the cage of fish. Fundulus invariably responded to the discharge of the gun at 100 feet from the cage; they usmally responded at 200 feet; but they never responded at 500 feet. From these observations it is erident that the eflect of the report of a gun is distinctly local and in this respect it resembles the motor-boat noises.

It would be a matter of great interest to ascertain what influence the fring of heary guns has on fishes, but thus far no good opportunity for prosecuting such intestigations has been found. Through the comrtesy of the commanding oflicer of the United States revenue cutter Gresham it was possible to study the etlect of the explosion of a saluting charge of 2 pounds of powder from a 6 -pound howitzer. In these tests a considerable number of Fundulus were retained in a cage and the tests made at varying distances from the gun. At 2,000 feet no response was given to the report, and the same was true at 1,000 feet. Within 30 feet of the gun the conditions for accurate observation, because of the heary detonation, were very unfarorable, but the response at this position was at most only momentary and certainly not more striking than the reaction to the report from a fowling piece.

From these observations it seems quite clear that single, loud noises generated in the air enter water to a small extent, but in sufficient rolume to disturb momentarily fishes that are in the immediate vicinity. But even this limited disturbance does not seem to be produced by the ordinary motor boat which, partly because of the faintness of its sound under water and partly because of the gradual increase and decrease of the sound in intensity as the boat approaches and receles, is relatively inert so far as many fish are concerned. 


\section{CERTAIN SOUNDS ATTRACTIVE TO FISHES.}

The problem of the relation of fishes to sounds is almost always taken up from the standpoint of negative reaclion. in that it is assumed that noise drives fishes away. It must be remembered, however, that there are fisher, like the drumfish and especially the squetengue, that produce noises which are without much doulst ooncerned with bringing the sexes together in the breeding season and that these noises, therefore, are not repellent hut serve to altuact. Cases of this lind show that it is possible that even artificial noises, if appropriate in character, might attract fishes, for momel, even when disagreenble to the human ear, is not of necessity always disturbing to fishes and might eren serve as a lure.

\section{CONCLUSIONS.}

The sounds produced by motor boats are extremely faint under water and have little induence on the motements and feeding of fishes. Such influence as they do have is temporaly and rely much restricted in local extent.

Fingle explosive somdi, like the report of a rum, may startle fish and cause them to cease feeding. but these responses are also tomporaly and local.

Although most someds ane repellent to fish, some may serve as lures to particular species. 



